\begin{tabular}{c}
\hline KEMAS 12 (1) (2016) 100-110 \\
Jurnal Kesehatan Masyarakat
\end{tabular}

\title{
THE COMMUNITY DIAGNOSIS OF FILARIASIS ENDEMIC VILLAGES IN PEKALONGAN CITY
}

\author{
Arum Siwiendrayanti, Eram Tunggul Pawenang, Sofwan Indarjo ${ }^{\varpi}$ \\ Public Health Department, Universitas Negeri Semarang
}

\begin{tabular}{l} 
Article Info \\
\hline Article History: \\
Submited October 2016 \\
Accepted June 2016 \\
Published July 2016 \\
\hline Keywords: \\
Filariasis; Endemic; \\
village; Pekalongan \\
\hline DOI \\
http://dx.doi.org/10.15294/ \\
kemas.v12il.4130
\end{tabular}

\begin{abstract}
The percentages of referrals for the first level health facilities visits are coming from Filariasis cases have increased to 11,699 until 2008. In Pekalongan City, there are 117 infected people in 2011. This study aims at investigating social determinants of filariasis endemic communities in several villages. Surveys using a cross-sectional study design, Population studies that tested positive for finger blood survey (FBS) in 2011-2013. Samples were collected by convenience sampling method sequentially through questionnaires and observation. There were 402 people participating in this study. The result shows that the presence of bushes, puddle, Sewerage are in unfavorable conditions and people do not use mosquito net during sleep and hang clothes. The best prevention practice in Padukuhan Kraton Village is by regularly use mosquito repellent and do not go out at night, Padukuhan Kraton endemic filariasis with mf-rate of 3.7\%. Filariasis Elimination Program Year 2011-2015 is carried out properly and in accordance with the regulations of filariasis filariasis Mass Drug Administration (MDA) program. FBS is implemented before MDA (Mass Drug Administration) and handling of cases of chronic filariasis. Respondents have a good knowledge of prevention of transmission of filariasis. Hoewever, the practice of taking the MDA medication is still less. Suggestions for the community are to improve environmental sanitation, improvement of MDA medication and the prevention of transmission of filariasis.
\end{abstract}

\section{Introduction}

Filariasis is a systemic infection which is caused by filarial worm. The adult worms live in lymph nodes and human blood. This worm is biologically transmitted by insects (mosquitoes). The disease can be chronic disease and if not treated well, it will cause permanent disability in the form of enlargement legs, arms, breasts, and genitals in women and men. The disease is caused by three species of filarial worms which are Wuchereria bancrofti, Brugia malayi, dan Brugia timori.

In Indonesia, it is estimated that 6 million people are infected with filariasis until 2004 and 8,243 of them are clinical. The case of filariasis is increaseed to 11,699 patients in 2008 (Ditjen PP \& PL, 2008). Based on the report until 2009, from all regencies and cities, the reported filariasis chronic cases are as many as 11,914 cases. Filariasis can be transmitted by all types of species of mosquitoes. In Indonesia, there are more than 23 types of filariasis vector mosquito consisting of genus Anopheles, Aedes, Culex, Mansonia, and Armigeres.

Central Java has 451 patients of filariasis spreading across 25 regencies/cities in 2010 and there are 2 regencies, Pekalongan City and Pekalongan Regency which become endemic areas. In 2011, as many as 537 cases of filariasis patients are from 141 new cases, which 125 cases are found in Pekalongan and the rest is spreading over 8 other regencies. In 2012, the number of filariasis cases is 565 patients with 10 new cases in 8 regencies.

The largest contributor of filariasis cases in Central Java is Pekalongan City. Based on the 
results of a finger blood survey conducted by the Health Office in 2010, the cases of filariasis in Pekalongan occur to 63 patients, with 55 clinical cases and 8 chronic cases. In 2011, the number of cases becomes 117 patients consisting of 110 clinical cases and 7 chronic cases. In 2012 the number of cases of filariasis becomes 66 patients consisting of 59 clinical cases and 7 chronic cases and in 2013, there are 7 clinical cases. From the finger blood survey, in 2010, the number of microfilaria rate in Padukuhan Kraton village is $3.39 \%$. In 2011, in the Padukuhan Kraton village there are 21 filariasis cases. In 2012, there are 10 new cases. And in 2013, there are 7 new cases.

Some factors can trigger filariasis events, for example environmental and behavior factors. Environment is one of the factors which affects the vector density of filariasis. Ideal environment for mosquitoes could be used as potential sites for mosquito breeding and resting place, so the numbers of mosquitoes will increase. Pekalongan City is an endemic for filariasis which are generally in low-lying areas, especially in the countryside, beaches, rice fields, swamps and forests. The neighborhood which consists of the physical, biological, social and cultural environments directly or indirectly affects filariasis. The physical environments, for example, a puddle of water, bushes, etc., are closely related to the life of the vector as well as the resting and breeding places for mosquitos.

Community diagnosis which is often called as public health assessment is an activity to determine the concerns expressed within community through a study. Diagnosis of the community is an important component in planning health programs. This activity assesses and connects the problems, needs, desires, and facilities available within a community. From these four relationships, a solution or intervention for problem solving is established. Study documentation of relevant documents and observation are conducted to obtain information. The underlying assumptions for conducting the observation are conditions in society, physical infrastructure and social events which can only be understood correctly and completely if the researchers investigate the real conditions and events directly. The purpose of observation is to gain an understanding of the conditions and social interaction. Besides, the study will examine closely the daily routines of people which usually are not considered significantly by the subjects of the study. The study also collects the data and information which are usually difficult to be explained by people (e.g. in the form of photos). Bias can occur because of the presence of researchers who can interfere with social situation which is happening

Although community diagnosis is often confused with the needs assessment, there are differences: a good community diagnosis is expected to be broad and cover various aspects of the community such as culture, social structure, the role of the community, and so forth; a diagnosis of a good community should be able to provide an image for the program planners on how is the life within an area, how health problems are central, how interventions are most likely to succeed, and how to evaluate a good program. Therefore, researchers are interested in conducting a study entitled "The Community Diagnosis of Filariasis Endemic Villages in Pekalongan City".

\section{Method}

This research was a survey using cross sectional study design that searched data at a time without intervention from the respondent. This research method used a mixed method approach which combined quantitative and qualitative approaches. A quantitative approach was more dominant, while the qualitative approach used as a supporting data. Quantitative research was conducted through survey, while qualitative research was conducted using the method of evaluation. The qualitative data is related to the needs identification, instrument validation by experts, and program implementation. Prior to the analysis, the validity of qualitative data was first checked under triangulation of sources. Qualitative data analysis was done by focusing on the accuracy of facts and empirical generalizations using the steps in the interpretation of data using comparative analysis method (Moleong, 2002).

The survey was conducted to see the magnitude of the problem of filariasis in populations in Pekalongan City as well as factors that contributed to the magnitude of the 
problem. The survey was carried out based on representative data by visiting the community to see most problems. The populations in this study were patients with filariasis from the survey results of finger blood in 2011-2013 and were recorded in villages in Kota Pekalongan, especially in Padukuhan Kraton Village, Bandengan village, Pabean village, Banyu Urip village, kertoharjo village, koripan lor village and Jengot Village.

The samples were collected using a convenience sampling method sequentially from patients with filariasis in Pekalongan city based on a survey of finger blood. The samples in this study were from 402 samples. This study used a population consisting of six units of study area residents. The six units were determined by purposive research area by selecting the endemic villages that are in the working area covered by the public health center/Puskesmas and the MDA program and had the highest number of filariasis cases during 2004-2012, namely Jenggot Public Health Center (Banyurip Ageng and Jenggot villages were selected), Padukuhan Public Health Center (Bandengan and Pabean Villages were selected), and South Pekalongan Public Health Center (Kuripan Lor and Kertoharjo Villages were selected). The populations of each unit were: Banyurip Ageng Village 5,256, Jenggot Village 11,491, Bandengan Village 6,413, Pabean Village 4,614, Kuripan Lor Village 6,034 and Kertoharjo Village 3,134. (Monographs of Banyurip Ageng, Jenggot, Bandengan, Pabean, Kuripan Lor, dan Kertoharjo; 2011; 2011). For the measurement of knowledge, attitudes, and practices before and after treatment, the study used stratified random sampling technique with minimal sample size which was calculated using the formula (Notoatmodjo, 2012).

The data collection was done by researchers through questionnaires and observation sheets. Based on the data that had been collected, the data was analyzed whether they reflected a deviation or aberration or not. In the clinical diagnosis, the data was usually compared with normal values. At the community level, it can be compared with the target, predictions, previous figures, or numbers on a wider area (regional, provincial or national). This process produced a set of data about the existence of "a deviation." Similar to clinical diagnostics, the data collection process would find a wide range of positive and negative findings or a collection of symptoms and complaints. Primary data from the survey on community and leaders of communities were grouped into quantitative or qualitative data. Qualitative data was conducted by grouping and codification process before further analysis. In general, the analysis used was descriptive analysis calculating the frequency or summarize the data. Secondary data usually displayed the aggregate data in the form of rate, ratio, proportion / percentage and average.

To define the methods of intervention, the determining factors which affect the health problem, resources and community ability to solve the problems had to be analyzed in advance. The next step to determine community diagnosis was to conduct the analysis of risk factors and resources for any health problems that had been identified from previous steps. A list of the risk factors and potential resources also had been identified in step three. Therefore, the next step was to make table which connects health problems, risk factors and resources. The method used could combine between theoretical analysis and then confirming to the available data.

\section{Results and Discussion}

The research conducted in the Kuripan Kertoharjo village shows that from 17 respondents have "sufficient" knowledge about the prevention of transmission of filariasis. There are 6 people who have "poor" environmental conditions (35.3\%) and 11 people who have "good" environmental conditions (64.7\%). From 53 respondents who have "good" knowledge about the prevention of filariasis transmission, there are 15 people who have "poor" physical environmental conditions (28.3\%) and 38 people who have "good" physical environmental conditions (71.3\%). Fifty three from seventy respondents have "good" knowledge about the prevention of filariasis transmission with the physical condition of the environment. This study shows that there is no correlation between the knowledge about the prevention of transmission of filariasis with the physical environmental conditions i.e. with $p=$ 
0.808 (>0.05). This happens due to lack of family support or health worker to the respondent to convince respondents that the physical condition of the environment is very influential as filariasis transmission. In accordance with the theory of Notoatmodjo (2012), although public awareness and knowledge about health is already high, the practice of public health remains low. The biggest obstacle to realize healthy behavior is some enabling factors. The environmental conditions are still "poor", 69 from 70 respondents live around wild bushes that are not regularly cleaned. The bushes are there to be the resting place of mosquitoes. Respondents know that bush is risky for filariasis transmission. But because the respondent do not get support in the form of facility, motivation, and confidence given by family members, cadres or health workers to create good physical environmental conditions as the prevention of transmission of filariasis, the environment remains bad.

Variable of attitude with physical environmental conditions shows that from 28 respondents who have "sufficient" attitude in the prevention of filariasis transmission, there are 13 people who have "poor" environmental conditions $(46.4 \%)$ and 15 people who have "good" environmental conditions (53.6\%). From forty two respondents who have "good" attitude about the prevention of filariasis transmission, there are 8 people who have "poor" physical environmental conditions $(19.0 \%)$ and 34 people who have "good" physical environmental conditions (81.0\%). It shows that from 70 respondents, there are 42 respondents who have "good" attitude about the prevention of filariasis transmission toward the physical conditions of the environment. This study shows that there is a relationship between attitudes about the prevention of filariasis transmission with the physical environmental conditions with $\mathrm{p}=0.029(<0.05)$. Odd Ratio (OR) 3,683 shows that people who have attitude of prevention of transmission of filariasis in the category "sufficient" are 3,683 times bigger in getting the risk of having poor physical environmental conditions as compared with the people with "good" attitude toward transmission prevention of filariasis transmission. This is because the respondents have confidence that physical environmental conditions greatly affect the transmission of filariasis. Therefore, the attitude of the respondents toward physical condition of the environment around their residence is also good. Good attitude of the respondents is not only found in certain job status, but randomly. That is because the belief in each family that the physical condition of the environment is important as prevention of filariasis. In accordance with the theory in Notoatmodjo (2012), attitude is a readiness or willingness to act without being driven by any particular motif. Attitudes consist of three components namely trust, evaluation of the object, and a tendency to act. Therefore, a good attitude on the prevention of transmission of filariasis is expected to create good physical condition environment as well.

The results of research conducted in Kuripan Kertoharjo village shows that from 15 respondents who are lack of practice in taking medication in the filariasis MDA, there are 9 people $(60 \%)$ who have knowledge about the prevention of filariasis in "sufficient" category and 6 people $(40 \%)$ who have "good" knowledge about the prevention of filariasis. For respondents who practice taking the filariasis medication in MDA well, from 55 people, there are 11 people $(20 \%)$ who have knowledge about the prevention of transmission of filariasis in "sufficient" category and $44(80 \%)$ who have knowledge about the prevention of filariasis in "good" category. This study shows that there is a relationship between knowledge about the prevention of filariasis with the practice of taking the medication in the Mass Drug Administration (MDA) in Kuripan Kertoharjo village Pekalongan City in 2015 with a value of $p=0.007(<0.05)$. The Odd Ratio (OR) of 6.0 indicates that the people with "less" knowledge about the prevention of transmission of filariasis have 6.0 times higher risk toward the practice of taking the medication in the MDA as compared with the people who have good knowledge of prevention of transmission of filariasis. It is because of people's curiosity about the high filariasis disease and behavior of people in prevention. Therefore they want take the drug prevention mass for filariasis. People who are lack to take medication practices of filariasis is lacking in the knowledge too. 
In accordance with the theory, knowledge is the result of 'knowing', this happens after a person is sensing a specific object. Most human knowledge is gained through eyes and ears senses. The finding is in line with the theory put forward by Roger in Notoatmodjo (2007) which states that behavior based on knowledge will be more lasting than that those which are not based on knowledge. It shows that knowledge is an important capital for the formation of one's actions, and most people have a high level of knowledge about the disease filariasis.

Attitude variable of taking practice of filariasis prenvention mass medical taking shows that from 15 samples who have lack of practice of filariasis MDA, there are 11 samples (73.3\%) who have the attitude about prevention of filariasis transmission in "sufficient" category and 8 samples $(26.7 \%)$ who have attitudes about knowledge on prevention of transmission of filariasis in "good" category. In the samples that have good practice of taking the filariasis drug, from 55 people, there are 26 people (47.3\%) who have the attitude of prevention of transmission of filariasis in "sufficient" category and 29 people (52.7\%) who have attitude on the prevention of transmission of filariasis in "good" category. This study shows that there is no correlation between attitudes about the prevention of filariasis with the practice of taking the filariasis Mass Drud Administration (MDA) in Kuripan Kertoharjo village with $\mathrm{p}=$ 0.113 (>0.05). This is because public attitudes about taking medication of filariasis show there is lack of support from the family. Family is more carefree in letting their family members to take medicine or not. The attitude is evaluative predisposition which mostly determines how an individual act. However, an attitude and concrete action are often much different, this is because the real action is not only grounded by attitude, but also there are a variety of other external factors. The realization of an act or attitude into real action takes several factors or conditions that would allow such facilities factors.

From the research that has been done, it can be concluded that the implementation of Filariasis Elimination program in Pekalongan City in 2011-2015, especially in Kuripan Yosorejo Village RW I-V has been carried out properly and in accordance with applicable regulations. Filariasis elimination program in Pekalongan is done with the main program MDA (Mass Drug Administration) or filariasis mass treatment with counseling. The other two main activities, namely FBS (Finger Blood Survey) is carried out before MDA and handling of cases of chronic filariasis. This is consistent with the objectives of filariasis elimination program which states that the overall objective of this program is to make sure that filariasis will not become public health problem in Indonesia in 2020. The specific purposes of the program are 1) to decrease the numbers of microfilariae rate to less than $1 \%$ in each regency and 2) to prevent and limit disability due to filariasis. Filariasis elimination program through a series of POMP in Kuripan Lor village in the years 2011-2015 includes the preparation for socialization in the village level, sharing drug monitoring and evaluation for filariasis and elephantiasis medicine division. Although the implementation in the field still require some change of strategy, it is allowed by the Pekalongan City Health Office associated with the approach to the community to achieve the program's goals. The approaches taken include MDA 2015 among school children by the Health Office of Pekalongan City simultaneously in schools about worm, education (socialization) of filariasis in Kuripan Lor village in 2015 by the South Pekalongan Public Health Center in 2015 up to the public via the "arisan" (regular social gathering) for the year previously only up to the village level, the distribution of drugs door to door as well as the monitoring and evaluation of drug division elephantiasis per village.

In evaluation results of filariasis elimination program of the behavioral aspects through promotion approach by South Pekalongan Public Health Center staffs, filariasis elimination personnel can be said to yet fully hit to the community or Kuripan Lor Village and Yosorejo Village RW I-V. Society is only limited to knowing how behavioral prevention practices of filariasis with taking medication, behavior to prevent mosquito bites and environmental preservation around the residence and has not yet reached the stage of practice. There is medicine consumption that has been practiced medicine and change the 
habits of people Kuripan Lor Village in 2011 as the beginning of a mass treatment program that can be said to be difficult to be accepted by society and by the end of the period of 2015 , it is easier based on the percentage of mass medical treatment which has reached $91 \%$. The other prevention practices to adjust to the condition of the house and family members include a habit of out at night, the habit of using mosquito nets, clothes hanging habit, and a habit of wearing long sleeves and long pants.

The results of the evaluation on environmental changes from 2011 to 2015 in Kuripan Lor Village show that the success cannot be realized because there is no policy on the prevention of filariasis by changing environmental conditions. The environmental change is part of Kuripan Lor village policy and it is outside the context of filariasis elimination program. The environmental changes in the domestic sphere include the existence of mosquito net, sewerage, bushes and aquatic plants completely not running yet. The information which is submitted is only able to add knowledge, However in practice, they have not been conducted. It is also because people adjust to the needs and condition of the house and family members.

The research in Jenggot Village Pekalongan in 2015 shows that there is no relationship between the habit of using insect repellent (0.031) with the incidence of filariasis, amounted to 32 case respondents (59.3\%) who have a habit of not using mosquito repellent and 22 control respondents (40.7\%) who have habit of not using mosquito repellent. While the variables associated with the incidence of filariasis is a habit out of the house at night (0.670), there were 20 case respondents $(52.6 \%)$ who have habit of cases out of the house at night and 18 control respondents (47.7\%) who have a habit out of home at night. The habit of using a mosquito net $(1,000)$ shows that there are 40 case respondents (50\%) who do not use mosquito nets cases and 40 control respondents (50\%) who do not use the nets control. Dealing with the practice of cleaning the bushes (0.134), there are 9 case respondents $(69.2 \%)$ who do not clear brush and 4 control respondents (30.8\%) who do not clean the bushes. The use of gauze wire (0.133) shows that there are 43 case respondents (52.4\%) who do not use a wire gauze and 39 control respondents $(47,6 \%)$ who do not use a wire gauze.

In the study site, there are respondents who do not have the habit of using insect repellent due uncomfortable feeling with the sticky effect of insect repellent, as well as because they forget to use mosquito repellent. One way to prevent from mosquito bites is to use repellent. This self-protection method is used by individuals or small groups in communities to protect themselves from mosquito bites. Because the repellent is relatively small, it is easy to carry and simple in use such as: burned, coils, topical repellent (Ike, 2013). The habits of going out of the house do not seem to correlate with the filariasis. This possibly because when respondents engage in activities outside the home at night, some of them have used topical insect repellent. The habit of going out at night are particularly at risk for being bitten/mosquito contact Cx.quinquefasciatus where it is known that the pattern of biting activity is outside the house all night with 3 peak densities at 21:00 to 22:00. 24.00-01.00 and at 2:00 to 3:00. The activity of Cx.quinquefasciatus mosquito inside and outside the house is associated with the pattern of transmission of filariasis (Tri, 2009).

There are several possibilities that result in no significant association between the habits of using nets with an incidence of filariasis. This is because only a few respondents who use mosquito nets while sleeping at night. The proportion between the case respondents and the control respondents cases control the habit of using nets at least that's the habit of using bed nets cannot be compared because there is no difference between the case group and the control group. The principle of the use of mosquito nets is an attempt to prevent contact with mosquitoes, any type of netting used by respondents during sleep, keep being an important effort in order to prevent transmission of filariasis disease. However, the use of mosquito nets would be meaningless if it is not followed by the routine use by a person. The practice to use mosquito nets when sleeping theoretically contributes in the prevention of filariasis because in general, the highest mosquito biting activity is at night (Adrias, 2012). In RW 5 and RW 11 which 
are the research sites have bushes around houses, both which are well-maintained and wild. In addition, the area is also adjacent to the Kertoharjo Village, where the Kertoharjo Village filariasis is endemic areas with a high rate Mf in Pekalongan City, namely $4.8 \%$ in 2012. The border between the Jenggot Village and Kertoharjo Village is only marked by the garden and wild bushes. The border is close to RW 5 and RW 11 in Jenggot Village where the area have many filariasis cases. Possible sources of transmission of filariasis are in the bush border between the Jenggot Village and Kertoharjo Village. The closer the respondent's house with bushes, the more likely the respondent is in contact with the mosquito Culex quinquifasciatus (Ike, 2013). The research site notes that only a small proportion of respondents who use gauze wire on ventilation in all parts of the room of his house in good condition. This is because the respondents have been using mosquito coils, spray and topical, and respondents who have been using mosquito nets no longer need to wear a gauze wire on ventilation in every room of the house. Wire gauze which is installed in all home ventilation can serve as screening to prevent mosquitoes inside the house. So the gauze wire mounting efforts is to reduce contact between mosquitoes with existing residents in the house (Adrias, 2012).

The results from Padukuhan Kraton Village is known that around the house of cases respondents with wild bushes have 10 people $(35.7 \%)$ and around the house of control respondents there are 2 people (7.1\%). Around the house of cases respondents with puddles have 23 people $(82.1 \%)$ and around the house of control respondents have 27 people $(82.1 \%)$. The case respondents have Sewerage with bad condition with 25 people (89.3\%) and control respondents are as many as 23 people (82.1\%). The case respondents that do not wear a mosquito net while sleeping are as many as 24 people $(85.7 \%)$, and control respondents are as many as 13 people (46.4\%). The case respondents that do not use wire gauze on ventilation are as many as 26 people (92.9\%), while control respondents are as many as 23 people $(82.1 \%)$. The cases respondents who have a habit of hanging clothes are as many as
21 people $(75.0 \%)$ and control respondents are as many as 14 people (50.0\%).

Based on research in the field shows that the relationship where the bushes with the incidence of filariasis, because the proportion of the presence of bushes around the house respondent cases greater than the respondent control. Although the presence of bushes around the house respondent is not much, but the presence of bushes included in the physical environment that can affect mosquito density. The physical environment is closely related to the life of Ventor, and therefore contributes to creating sources of transmission of filariasis. The existence of the bush is one of the risk factors to the incidence of filariasis, hence the need for action to break the chain of transmission of filariasis. Based on the results of the study in the journal Environmental Health on the Relationship Conditions Home Environment, Social Economy and Society by Genesis Behavioral Filariasis in the District of South Pekalongan Pekalongan mention that the existence of the bushes is a haven for $\mathrm{Cx}$. Quinquefasciatus when outside the home. The closer the respondent's house with bushes, the more likely respondents contact with $\mathrm{Cx}$. Quinquefasciatus (Windiastuti, 2013).

Based on the observations of researchers in the field thought to the factors that result no significant association between the presence of stagnant water with the incidence of filariasis in this location because the same environmental conditions between locations where respondent cases and controls are located in tidal flood prone area. Stagnant water is located in the Padukuhan Kraton Village is a pool of brackish water, which is a mixture of salt water to fresh water, because it comes from sea water mixed with rain water. Mosquitoes Cx.quinquefasciatus, as vectors of filariasis in Pekalongan, can not breed in the brackish water. Based on research conducted by Yoghi Gilang Pratama (2015) showed that the pool of brackish water is a suitable place and favored by the type of Anopheles mosquitoes.

The results showed that the alleged Sewerage is not a risk factor for the transmission of filariasis in this village, as respondents in the case and control groups had the same Sewerage open and flooded. Another factor that causes 
no significant relationship between the Sewerage condition with the incident because in the Village Padukuhan Kraton has the same environmental conditions that often occur tidal flood, so Sewerage often overflows and the resulting inundation caused water volume rob high and water flow is inhibited and can not be flows out into water bodies. In addition, most of Sewerage in Sub Padukuhan Kraton especially in RW 13 and RW 14 is mixed with water at Sewerage batik waste, so that mosquitoes can not breed filariasis in the Sewerage conditions. Sewerage conditions are bad or open waste water channel according to Mardiana (2007), have a greater risk is 2.56 times to hit filariasis compared enclosed channel. Their sewerage unwrapped effect on the incidence of filariasis in the past 12 months, therefore the open sewer that led to the availability of good breeding grounds for the mosquito vector is Culex quinquefasciatus filariasis.

Research in the field there is a relationship between the use of mosquito nets while sleeping with the incidence of filariasis, respondents who did not use mosquito nets while sleeping at risk 6.9 times more likely than respondents filariasis nets while sleeping. The results of research in the field with the respondents that found many respondents who do not use nets because the average respondent had used anti mosquito and feel uncomfortable if you sleep under a mosquito net, so that many respondents do not want to use mosquito nets. According to Blum the factors affecting health status including filariasis among other factors behavior. It is people's behavior affects the incidence of filariasis among other man made breeding places, the behavior does not use mosquito nets, sleeping late unprotected (Repellent / jacket / long sleeves).

Research in the field indicates that some of the allegations that result in no significant association between the use of chicken wire with an incidence of filariasis as found in only some of the respondents who use a wire gauze on ventilation in all parts of the room of his house, it's probably because the respondents who had been taking anti mosquito / topical, mosquito nets, so no need to use wire netting on the ventilation in every room of his house. Another factor is the installation of wire netting at home is influenced also by economic factors respondents. The bivariate analysis showed that some of the allegations that result in no significant association between habitual hang clothes with the incidence of filariasis among others, respondents of both groups the majority $(62.5 \%)$ had the same habit that is hanging clothes that are worn in the house, for clothing the respondents still want to be used again, in the respondent's house there are family members who attend school or work that requires longer wear clothes that are hung and the lack of knowledge about the habit of hanging clothes in the house is the resting place of filariasis vector carrying mosquitoes because mosquitoes like place- place protected from the sun and light.

The best prevention practices in Padukuhan Kraton is the installation of mosquito repellent (100\%) and the worst prevention practices are not out at night (12.5\%). In 2012 carried out a survey which finger blood results show that Padukuhan Kraton endemic filariasis with mf-rate of $3.7 \%$. Mf-rate high in this village because there are many people who go out at night at high clock mosquito bites (20:00 to 21:00 hours). Habits carried out night of Village residents cause vulnerable citizens to obtain filariasis vector mosquito bites.

The best prevention practices in Bandengan is the practice of taking medication (90.9\%) and the prevention of the worst practices is mounting the screen on ventilation air $(0 \%)$. In 2010, conducted a survey which showed that finger blood mf-rate Bandengan Village is $2 \%$. Mf-rate high in this village is suspected because of the absence of public participation in the prevention of filariasis by installing netting on the air vents. The absence of citizens who put gauze on the air vent is because the citizens feel that the installation of netting on the air vents are very expensive. On the other hand, the installation of ventilation gauze at home by residents is an attempt to protect themselves against mosquito bites, but without realizing this activity to distance themselves from the risk of acquiring filariasis (Febrianto, 2008).

The best prevention practices in Kuripan Yosorejo is the practice of taking medication (90.9\%) and the worst thing is the installation of netting on the air vents (9.1\%). In 2010 
conducted a survey showing that the finger blood mf-rate in this village is $0 \%$. Although mf-rate at $0 \%$ of this village, but residents should still take precautions filariasis. In this village needs to be improved is the installation of wire netting on the air vents. Based on the results of the study, residents do not put gauze on the air vent on the grounds that it did not know the function of the installation gauze in the air vents. According to Rizki Amelia (2014), that the wire netting is installed on all home ventilation can serve as screening to prevent mosquitoes from entering the house.

The best prevention practices in Kuripan Kertoharjo is the installation of mosquito repellent (100\%) and the prevention of the worst practices is the installation of netting $(16.7 \%)$ and mounting the screen on ventilation air (16.7\%). In the year 2012, conducted a survey which showed that finger blood mf-rate in Sub Kuipan Kertoharjo was 2.4\%. The low use of nets to be one factor causing the high mfrate in this village. Based on the results of the study, the low participation of citizens in the use of mosquito nets because citizens feel hot when using mosquito nets. On the other hand, the habit of using mosquito nets at bedtime theoretically have contributed to preventing the transmission of filariasis, because in general the highest mosquito biting activity at night (Julius Sarungu, 2012). In addition, according to residents of the installation of netting on the air vent is not so important to be implemented. This contrasts with research conducted by Puji Juriastuti, et al (2010) which states that the respondents did not have a wire gauze in her home 7.2 times greater risk of suffering from filariasis compared to respondents who do not use a wire gauze.

The best prevention practices in Banyurip is the practice of taking medication (72.7\%) and clearing bushes (72.7\%), while the worst prevention practices is the installation of netting $(0 \%)$. In the finger blood survey in 2012 , it is known that the mf-rate in Banyurip is $0.5 \%$. Although mf-rate is $<1 \%$, residents should still take precautions. One precaution that must be done is to install mosquito nets while sleeping. Based on this research, it is known that at least the people who put up a mosquito net because the residents are not accustomed to sleep using mosquito nets. In addition, according Ardias (2012), the principle of the use of mosquito nets is an attempt to prevent contact with mosquitoes, the type of netting any used by the respondent at the time of sleep, remain an important effort in order to prevent transmission of disease filariasis, but the use of mosquito nets would be meaningless if not followed by the use of routine by a person.

The best prevention practices in Jenggot is the practice of taking medication (95.2\%) and the prevention of the worst practices is mounting the screen on ventilation air (9.5\%). Based on the survey results finger blood in 2012, it is known that the village Beard mf-rate is $5 \%$. Mf-rate high in Jenggot allegedly due to lower behavioral prevention is not a night out in the village. Residents did not realize that his behavior was out the night can increase the chance of contracting the filariasis. Activity at night as teaching activities, talking with neighbors, or other activities may increase the risk of contracting the filariasis when not using personal protective equipment from mosquitoes filariasis.

Bandengan Village has risk factors such as bushes, cattle sheds, marsh coast, and Sewerage open. The condition of the bushes in Bandengan Village is entirely a thicket. Almost all Sewerage are in the right - left the road and containing mosquito larvae. The existence of people in Bandengan Village are around Sewerage and tidal inundation.

Environmental risk factors in Pabean Village are the existence of swamps, tidal inundation, and open Sewerage open. Open Sewerage are located in the right and left of the road and containing mosquito larvae. The existence of the bushes are in the eastern and southern border of Pabean Village. There is no bushes in this district because it is inundated by rob. The location is close to patient risk factors such as open Sewerage.

Banyurip Ageng Village has risk factors such as livestock barns, fields, open and closed Sewerage, and bushes. In some open Sewerage which contain no waste of batik, the presence of mosquito larvae is detected. The existence of the bush is divided into two, namely the presence of shrubs and bushes groomed evenly distributed almost all areas of the village. The 
risk factors puddles form of rice which is on the north, west, and south regions of Banyurip Ageng. Patients location is around the shrubs, wild bushes and open Sewerage.

Kuripan Lor Village has risk factors such as open and closed Sewerage, animal pens, marshes, rice fields and bushes. From the map, the proportion of the presence of closed Sewerage is more than the open Sewerage. There are shrubs and bushes groomed at this location and the proportion of groomed shrubs is more than shrubs. Rice field has a little proportion and is in the eastern border of Kuripan Lor village. No resident is positive microfilariae in Kuripan Lor so there is no patient point at this location.

Jenggot Village hasrisk factors such as open and closed Sewerage, fields and bushes. Uneven Sewerage are in all parts of the village but from the map, the coverage of SPA looks more dominating in the central region of villages with more dense residential areas. There are some bushes in this area. In addition, the rice field has smaller proportion and is on one the side of the administrative border between Jenggot and Kertoharjo villages. The patient points are in RW V and RW XI which are close to the area of Kertoharjo. Patient point is close to where the rice paddies, fields, open sewerage, and bushes exist.

Kertoharjo Village has risk factors such as livestock barns, fields, shrubs, wild bushes, and open Sewerage. Rice fields in Kertoharjo are in the middle and the west side of the Village. Patients with positive microfilaria are distinguished by the latest case, and the cumulative incidence of a few years earlier. The existence of patients is around the cattle sheds, shrubs, wild bushes, open Sewerage containing mosquito larvae, fields and rice paddies.

Based on the results of the study, it indicates that there is a presumption that the existence of a bush is related to the incidence of filariasis in Pekalongan City. This is evidenced by research conducted by Ike (2013) in the South Pekalongan regency that the resting place of mosquitoes such as shrubs, hanging clothes, and cattle are associated with the incidence of filariasis ( $p$-value $=0.025$ ). In addition, the presence of risk factor which is allegedly linked to the incidence of filariasis in Pekalongan is the livestock corral. In the district of Muara Jambi, it shows that people who have livestock barns that are attached to the house have 29.2 times greater risk of contracting the filariasis than those who separate the cattle barn. Mosquito breeding sites are in the puddles. Puddles which are observed in this study are the ecosystem with flooded habitat and In contact with the ground, for example rice paddies, swamps, and tidal inundation containing mosquito larvae. Components of puddle swamp and rob in Pabean Village and Bandengan Village are not a component that has been linked to the transmission of filariasis in Pekalongan. In previous studies, it is demonstrated that the presence of predatory fish in stagnant water such as swamps around the house will reduce the risk of filariasis 1 time than those which do not contain predatory fish. In addition, research by Yudi (2012) in Pekalongan Buaran and Tirta villages, it shows that there is no relationship between the presence of a swamp with the incidence of filariasis. Additionally, locations of the patient in six villages are entirely contiguous with risk factors for Sewerage around their home. There is a presumption that the existence and condition of Sewerage has been associated with the incidence of filariasis in six locations. Based on the results of Ardias (2012), respondents whose houses contain mosquito habitat (breeding place) have 38.031 times greater risk of suffering from filariasis compared with respondents who not contained mosquito habitat.

\section{Conclusion}

The existence of bush, puddles, bad Sewerage, not using any wire netting on the ventilation and variable hang clothes. The best prevention practices in Padukuhan Kraton village is by installing insect repellent, do not go out at night. Padukuhan Kraton Village is an endemic filariasis with $\mathrm{mf}$-rate of $3.7 \%$. The use of mosquito nets while sleeping is important. Filariasis Elimination Program Year 2011-2015 Pekalongan has been broadly implemented properly and in accordance with applicable regulations. Filariasis elimination program in Pekalongan City with the main program MDA accompanied by counseling program. FBS is implemented before MDA and handling 
of cases of chronic filariasis. Respondents have good knowledge about the prevention of filariasis transmission and the practice of medicine in the MDA filariasis,

\section{References}

Amelia, R. (2014). Analsis Faktor Risiko Kejadian Filariasis, Semarang Indonesia. Unnes Journal of Public Health, 3(1).

Ardias, dkk. 2012. Faktor Lingkungan dan Perilaku Masyarakat yang Berhubungan dengan Kejadian Filariasis di Kabupaten Sambas. Jurnal Kesehatan Lingkungan Indonesia, XI(2):199-207.

Bagus Febrianto, dkk. 2008. Faktor Risiko Filariasis di Desa Samborejo Kecamatan Tirto Kabupaten Pekalongan Jawa Tengah. Buletin Penelitian Kesehatan, 36(2): 48-58.

Bina Ikawati dan Tri Wijayanti. 2010. Pengetahuan, Sikap dan Praktik Masyarakat Kelurahan Pabean, Kecamatan Pekalongan Utara Kota Pekalongan Tentang Filariasis Limfatik, Jurnal Ekologi Kesehatan, 9(4).

Dina Agustiantiningsih, Praktik Pencegahan Filariasis. 2013. Jurnal Kesehatan Masyarakat, VIII(2): 190-197.

Ditjen PP \& PL. 2008. Pedoman Program Eliminasi Filariasis $D i$ Indonesia. Departemen Kesehatan Republik Indonesia, Jakarta.

Hasmiwati, Nurhayati. 2009. Kajian Nyamuk Vektor Di Daerah Endemik Filariasis Di Kenagarian Mungo, Kabupaten Lima Puluh Kota. Jurnal Kesehatan Masyarakat, 3(2).

Hutagalung, J. 2010. Faktor Risiko Kejadian Penyakit Lymphatic Filariasis di Kabupaten Propinsi Sumatera Barat, Tahun 2010. Jurnal Outbreak Surveillance and Investigation, 7 (1): 9-15.

Juriastuti, P. Kartika, M. Djaja, M. 2010. Faktor Risiko Kejadian Filariasis diKelurahan Jati sampurna. Jurnal Makara Kesehatan, 14(1):31-36.

Ike Ani Windiastuti, dkk, 2013, Hubungan Kondisi Lingkungan Rumah, Sosial Ekonomi, dan Perilaku Masyarakat dengan Kejadian Filariasis di Pekalongan Selatan Kota Pekalongan, Jurnal Kesehatan Lingkungan Indonesia, Volume XII, No 1, April 2013, hlm. 51-57.

Mardiana, Enny Wahyu Lestari, Dian Perwitasari, 2010, Faktor-Faktor yang Mempengaruhi
Kejadian Filariasis di Indonesia, Jurnal Ekologi Kesehatan, Vol. 10, No. 2, hal 83 - 92 Notoatmodjo, Soekidjo, 2012, Promosi Kesehatan dan Perilaku Kesehatan, Rineka Cipta, Jakarta.

Pratama, Gilang Yoghi, 2015, Nyamuk Anopheles sp dan Faktor yang Mempengaruhi di Kecamatan Rajabasa, Lampung Selatan, Medical Journal Of Lampung University Vol. 4, No.1, 2015 hal 20-17,

Puji J, Maya K, I Made D, Dewi S, 2010, Faktor Risiko Kejadian Filariasis Di Kelurahan Jati Sampurna, Makara, Kesehatan, VOL. 14, NO. 1, JUNI 2010: 31-36

Risky Amalia, 2014, Analisis Faktor Risiko Kejadian Penyakit Filariasis, Unnes Journal of Public Health, Volume III, No 1, Maret 2014, hlm. $1-12$.

Santoso, 2007, Hubungan Kondisi Lingkungan dengan Kasus Filariasis di Masyarakat (Analisis Lanjut Hasil Riskesdas 2007), Jurnal Aspirator, Volume III, No 1, Tahun 2011, hlm. 1-7.

Satri Mayu Santi, dkk., 2014, Efektifitas Pendidikan Kesehatan Menggunakan Media Audiovisual Terhadap Perilaku Pencegahan Filariasis, Jom Psik Vol. 1 No. 2, Oktober 2014, Hal 2-8

Sudomo M, Kasnodiharjo, Santoso SS, 1994. Penularan Filariasis di Pemukiman Transmigrasi Kumpeh Ditinjau dari Aspek Sosio Antropologi. Buletin Penelitian Kesehatan, 22 (1), pp. 48-56.

Tri Ramdhani dan Bambang Yunianto, 2009, Aktivitas Menggigit Nyamuk Culex Quinquefasciatus di Daerah Endemis Filariasis Limfatik Kelurahan Pabean Kota Pekalongan Provinsi Jawa Tengah, Jurnal Aspirator Volume 1, No 1, 2009

Yudi Syuhada, 2012, Studi Kondisi Lingkungan Rumah dan Perilaku Masyarakat Sebagai Faktor Risiko Kejadian Filariasis di Kecamatan Buaran dan Tirto Kabupaten Pekalongan, Jurnal Kesehatan Lingkungan Indonesia Vol. 11 No. 1 / April 2012

Yulius Sarungu P, Onny Setiani, dan Sulistyani, 2012, Faktor Risiko Lingkungan dan Kebiasaan Penduduk Berhubungan Dengan Kejadian Filariasis di Distrik Windesi Kepulauan Yapen Provinsi Papua, Jurnal Kesehatan Lingkungan Indonesia vol 11 No.1 April 2012. 